KONSTRUKTIVISME, Vol. 10, No. 2, Juli 2018

p-ISSN: 1979-9438; e-ISSN: 2442-2355

FKIP Universitas Islam Balitar, Blitar

Http://konstruktivisme.unisbablitar.ejournal.web.id; Email: konunisba@gmail.com

\title{
PENERAPAN METODE CERIA PERMANIS UNTUK MENINGKATKAN PARTISIPASI DAN PRESTASI BELAJAR PKN SISWA KELAS VII SMPI HIDAYATUL 'ULUM DAYU SEMESTER GENAP TAHUN PELAJARAN 2017/ 2018
}

\author{
Minto Santoso \\ Program Studi PPKn Universitas Islam Balitar Blitar \\ Email: pu3mizan@gmail.com
}

\section{ABSTRAK:}

Metode mengajar di dalam kelas yang tepat dan bervariasi dapat dijadikan sebagai alat untuk memotivasi siswa dalam kegiatan belajar mengajar di sekolah.Dengan menggunankan metode mengajar yang bervariasi, maka akan dapat menghindarkan siswa dari rasa kebosanan, sehingga siswa akan tetap bersemangat dalam mengikuti pelajaran sampai pelajaran usai, bahkan merasa kurang waktu untuk mempelajari mata pelajaran tersebut. Rendahnya partisipasi siswa dalam pembelajaran di kelas VII SMPI ditemukan gejala rendahnya minat dan perhatian siswa terhadap pelajaran, rendahnya semangat siswa dalam melaksanakan tugas-tugas belajar dan mengikuti pembelajaran, rendahnyareaksi siswa terhadap stimulus yang diberikan oleh guru.Kondisi ini diusahakan diselesaikan dengan sebuah tindakan perbaikan melalui metode berceramah dengan berbagai variasi, permainan dan kuis.Hasil dari tindakan yang dilakukan memberikan dampak positif dalam pembelajaran yakni meningkatnya partisipasi siswa, kenaikan rata-rata kelas dan juga kenaikan jumlah ketuntasn belajar siswa. Peningkatan partisipasi siswa dalam pembelajaran PKn dari pra hingga berakhirnya tindakan sebesar $72,2 \%$. Peningkatan ketuntasan siswa dari pra siklus hingga evaluasi akhir sebesar 35,4\%. Peningkatan ini menunjukkan bahwa penggunaan metode ceria permanis efektif diterapkan di kelas VII SMPI Hidayatul 'Ulum Dayu pada semester genap tahun pelajaran 2017/ 2018.

Kata Kunci: metode, ceria, permanis, partisipasi, siswa, hasil, belajar 
Minto Santoso. 2018. Penerapan Metode Ceria Permanis untuk Meningkatkan Partisipasi dan Prestasi Belajar Pkn Siswa Kelas VII SMPI Hidayatul ‘Ulum Dayu Semester Genap Tahun Pelajaran 2017/ 2018. Konstruktivisme, 10 (2): 163-177

\section{PENDAHULUAN}

Di tengah situasi masyarakat yang multi emosi, pendidikan yang menjadi basis dan kawah candradimuka peradaban jelas menghadapi tantangan yang makin rumit dan kompleks. Dunia pendidikan tak hanya dituntut untuk mentransfer ilmu pengetahuan kepada siswa didik, tetapi juga harus mampu menjalankan peran dan fungsinya untuk menaburkan, menanamkan, menyuburkan, dan sekaligus mengakarkan rasa nasionalisme, nilai-nilai akhlak dan budi pekerti, sehingga keluaran pendidikan benar-benar menjadi sosok yang "utuh" dan "paripurna", menjadi pribadi yang berkarakter jujur, rendah hati, dan responsif terhadap persoalan-persoalan kebangsaan, menjadi insan yang berkeseimbangan jasmani rohani, lahir batin dan dunia akhirat. Itulah kiranya apa yang menjadi garis besar tujuan pendidikan nasional yang harus dipahami oleh semua pihak utamanya para pemerhati dan pelaku dunia pendidikan serta mengimplementasikaanya dalam setiap mata pelajaran yang telah disepakati dalam kurikulum nasional. Semua lini dan materi pendidikan haruslah mampu menumbuhkan dan mengembangkan kesadaran serta kemampuan fisik, intelegensi, psikologi, sosiologi, religi, dan kepribadian siswa. Hal ini dimaksudkan agar ada keseimbangan dalam diri pribadi siswa dalam rangka menjalani fungsinya sebagai personal individual dan komunal sosial. Namun yang sering terjadi para guru masih banyak yang berpandangan bahwasanya tugas mereka dianggap tuntas dan selesai dengan menyampaiakan materi secara menyeluruh sesuai dengan tuntutan kurikulum, tanpa memperhatikan adanya perubahan sikap dan tingkah laku peserta didik. Dengan kondisi yang semacam ini menyebabakan pelajaran PKn terkesan sebagai mata pelajaran yang ringan dan sepele, yang tanpa dibimbing oleh seorang gurupun siswa mampu untuk membaca dan menjawab pertanyaan-pertanyaan dengan sendirinya.

Sikap guru yang hanya mengejar target nilai semata sangatlah berdampak negatif terhadap proses pembelajaran. Terbukti ketika guru melaksanakan pembelajaran, di dalam kelas sering terjadi berbagai pelecehan. Diantaranya (1) siswa berbicara dengan teman, (2) siswa tidur atau melamun, (3) siswa mengerjakan tugas atau materi yang lain, (4) tidak fokus pada penjelasan guru, (5) bahkan bermain-main dengan apapun yang ada di dekatnya, seperti pensil, kertas atau hal lain yang dapat digunakan untuk mengalihkan perhatian. Sementara itu sang guru dengan susah payah memberikan penjelasan di depan kelas. Pada hakikatnya, hal sebagaimna di atas terjadi karena di dalam diri siswa tersebut tidak terdapat daya pendorong (motivator) sebagi penggerak dalam melakukan kegiatan belajar. Disamping itu banyak hal yang menyebabkan pembelajaran yang kurang menarik dan menyenangkan sehingga rangsangan belajar yang minim ini menimbulkan pencapaian hasil yang didapat pun tidak bisa mencapai tingkat yang optimal.Sebuah tuntutan yang diarahkan pada seorang guru, yaitu haruslah 
Minto Santoso. 2018. Penerapan Metode Ceria Permanis untuk Meningkatkan Partisipasi dan Prestasi Belajar Pkn Siswa Kelas VII SMPI Hidayatul ‘Ulum Dayu Semester Genap

Tahun Pelajaran 2017/ 2018. Konstruktivisme, 10 (2): 163-177

peka terhadap sikap dan tingkah laku siswa-siswinya di kelas sehingga ketika menghadapi permasalahan seperti di atas, dapat dengan mudah menemukan cara untuk memelihara serta membangkitkan motivasi belajar bagi siswasiswanya. Salah satu cara yang dapat dilakukan oleh guru untuk meningkatkan motivasi belajar siswa adalah dengan menggunakan metode mengajar yang bervariasi. Sebagaimana dinyatakan oleh Djamarah dan Zain (2010) bahwa metode mengajar di dalam kelas yang tepat dan bervariasi dapat dijadikan sebagai alat untuk memotivasi siswa dalam kegiatan belajar mengajar di sekolah.Dengan menggunankan metode mengajar yang bervariasi, maka akan dapat menghindarkan siswa dari rasa kebosanan, sehingga siswa akan tetap bersemangat dalam mengikuti pelajaran sampai pelajaran usai, bahkan merasa kurang waktu untuk mempelajari mata pelajaran tersebut.

Pada umunya, sering dijumpai adanya tindakan dalam menyampaikan suatu materi, pihak guru hanya menggunakan metode ceramah. Khususnya mata pelajaran PKn, karena mungkin terlalu sulit untuk menemukan metode lain yang cocok dengan konteks materi yang akan disampaikan. Disinilah peran guru dituntut kreatifitasnya, karena metode pembelajaran apapun relative bisa diaplikasikan dalam mata pelajaran dan bab apapun yang ada. Seperti yang kita ketahui bahwa proses belajar mengajar yang menggunakan metode ceramah pada umunya lebih cenderung terpusat pada diri guru, sedangkan siswa cenderung sebagai peserta pasif. Jika apabila penggunaan metode ceramah semacam ini secara terus menerus dilakukan apalagi dengan caa monoton maka akan membuat siswa cepat bosan dan cenderung bersifat pasif. Oleh karena itu, perlu adanya kombinasi dengan strategi/metode mengajar yang lain, sehingga membuat siswa lebih aktif dalam kegiatan belajarnya dan tidak cepat merasa bosan.

Berdasarkan hasil observasi yang dilakukan di kelas VII SMPI Hidayatul Ulum Dayu Kecamatan Nglegok Kabupaten Blitar pada semester genap tahun ajaran 2017/ 2018didapati sebuah faktabahwa tingkat partisipasi aktif siswanya yang rendah terhadap mata pelajaran PKn. Hal ini dapat diketahui dari rendahnya

1. Minat dan perhatian siswa terhadap pelajaran

2. Semangat siswa dalam melaksanakan tugas-tugas belajar dan mengikuti pembelajaran

3. Tanggung jawab siswa di dalam mengerjakan tugas dan mengikuti pembelajaran

4. Reaksi siswa terhadap stimulus yang diberikan oleh guru, dan

5. Rasa senang dalam mengerjakan tugas dan mengikuti pembelajaran

Berdasarkan fenomena diatas, peneliti berupaya untuk melakukan suatu penelitian tindakandengan judul "Penerapan Metode Ceria Permanis 
Minto Santoso. 2018. Penerapan Metode Ceria Permanis untuk Meningkatkan Partisipasi dan Prestasi Belajar Pkn Siswa Kelas VII SMPI Hidayatul ‘Ulum Dayu Semester Genap Tahun Pelajaran 2017/ 2018. Konstruktivisme, 10 (2): 163-177

untuk Meningkatkan Partisipasi Dan Prestasi Belajar PKn Siswa Kelas VII SMPI Hidayatul 'Ulum Dayu Semester Genap Tahun Peajaran 2017/ 2018".Ceria Permanismerupakan akronim dari gabungan beberapa metode yaitu Ceramah Variatif, Permaianan dan Kuis.

Ahmadi (2013) menyatakan penggunaa metode ceramah akan membuat siswa cenderung pasif dan bila digunakan terlalu lama akan menimbulkan kebosanan pada siswa. Karena itu Sudirman (2011) mengusulkan penggunaan metode ceramah hendaknya juga memperhatikan prinsip-prinsip didaktif seperti : mengadakan persepsi, memotivasi siswa agar menjadi lebih terangsang dan bergairah dalam belajarnya. Dalam rangka mengatasi adanya kejenuhan pada diri siswa, maka metode ceramah hendaknya dikombinasikan dengan metode -metode lainnya seperti tanya jawab, permainan atau penugasan tertentu. Disamping juga dapat digunakan berbagai media atau alat peraga yang jelas dan menarik sehingga siswa memperhatikan penjelasan dari guru.

Permainan adalah kegiatan yang kompleks yang didalamnya terdapat peraturan, play dan budaya. Sebuah permainan adalah sebuah sistem dimana pemain terlibat dalam konflik buatan, disini pemain berinteraksi dengan sistem dan konflik dalam permainan merupakan rekayasa atau buatan, dalam permainan terdapat peraturan yang bertujuan untuk membatasi perilaku pemain dan menentukan permainan

Banyak jenis permainan yang sering dimainkan oleh para pelajar. Namun yang dimaksud perminan dalam hal ini adalah sebagai berikut :

1. Secara phisik

Adapun jenis permainan alternative-relevantif.Jenis permainan ini bahannya apa saja dan mengacu pada persesuaian materi belajar. Misalnya, ketika guru akan mengajar kedisiplinan, anak-anak dapat diajak membuat jadwal bersama-sama dari mulai bangun tidur sampai menjelang tidur lagi.

2. Secara konseptual

Apapun jenis dan bentuk permainan yang dilakukan, maka harus dapat mencerminkan upaya pengembangan konsep dasar materi.

3. Secara realistis

Wujud media permainan merupakan realitas intelektual seorang guru. Guru yang kreatif kaya akan ide-ide ilustratif sehingga hal-hal yang sifatnya memang abstrak dapat diwujudkan gambarannya secara konkret sehingga mudah membentuk kompetensi pemahaman.

\section{METODE}


Minto Santoso. 2018. Penerapan Metode Ceria Permanis untuk Meningkatkan Partisipasi dan Prestasi Belajar Pkn Siswa Kelas VII SMPI Hidayatul ‘Ulum Dayu Semester Genap Tahun Pelajaran 2017/ 2018. Konstruktivisme, 10 (2): 163-177

Dengan menggunakan pendekatan deskriptif kuantitaif penelitian tidakan ini mendiskripsikan mengenai peningkatan partisipasi dan hasil belajar yang diperoleh oleh siswa dalam bentuk numerik. Mengacu pada methode Kemmis dan M.C. Taggart yang terdiri dari 4 komponen yaitu: perencanaan, tindakan, observasi, dan refleksi, diagram alur desain penelitian ditunjukkan pada gambar berikut.

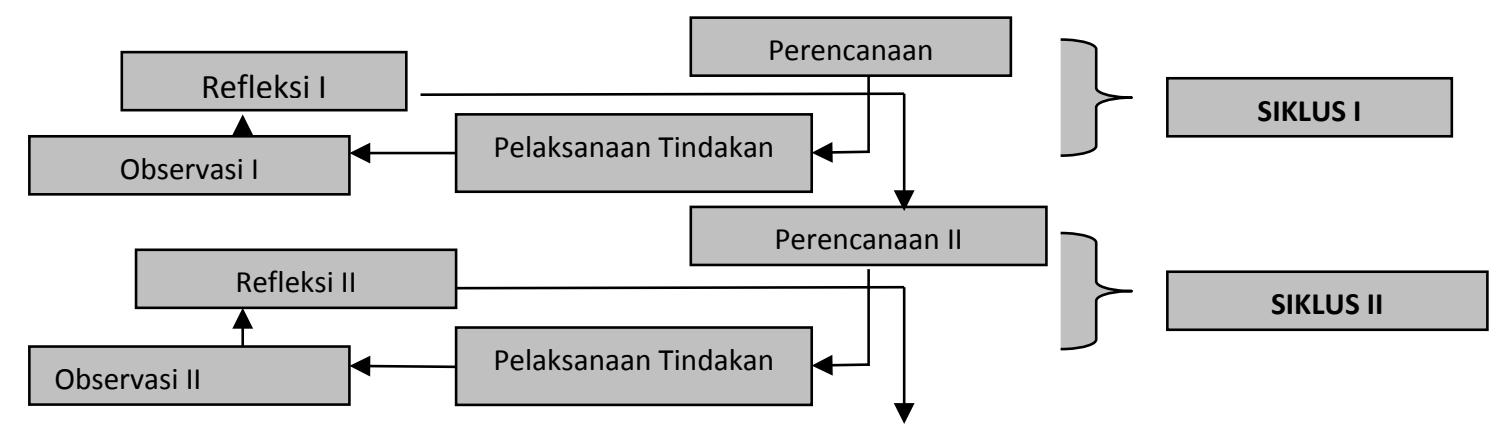

Gambar 1:Tahap-tahap Penelitian Tindakan Kelas menurut Kemmis \& McTaggart (dalam Arikunto, 2006:97).

Kegiatan yang dilakukan pada tahap perencanaan meliputi: a) menyusun rencana pelaksanaan pembelajaran dengan menggunakan metode ceria permanis sebagai tindakan perbaikan pada pembelajaran PKn, b) menyiapkan media pembelajaran kertas warna, c) pertanyaan untuk kuis, d) menyusun pedoman observasi, d) menyusun alat evaluasi siswa.

Langkah-langkah pelaksanaan tindakan untuk melakukan perbaikan pembelajaran $\mathrm{PKn}$ adalah:

1. Guru menjelaskan materi pembelajaran dengan ceramah variatif. Variasi yang digunakan dalam ceramah ini adalah disertai dengan tanya jawab, variasi intonasi, variasi tinggi rendah suara serta disertai dengan variasi perubahan gesture dan gerak tubuh,

2. Guru menata tempat duduk siswa sedemikian rupa sehingga dapat membuat alur seperti mata rantai yang tidak diketahui ujung pangkalnya

3. Guru membagikan kertas warna ukuran $5 \times 10 \mathrm{~cm}$ kepada semua siswa kemudian menginstruksikan siswa menuliskan namanya pada sudut kertas kemudian dilanjutkan membuat pertanyaan dari materi yang sudah dipelajari dan dituliskan pada kertas warna yang sudah dibagi. 
Minto Santoso. 2018. Penerapan Metode Ceria Permanis untuk Meningkatkan Partisipasi dan Prestasi Belajar Pkn Siswa Kelas VII SMPI Hidayatul ‘Ulum Dayu Semester Genap

Tahun Pelajaran 2017/ 2018. Konstruktivisme, 10 (2): 163-177

Guru mengecek pertanyaan yang dibuat oleh siswa supaya tidak sama satu dengan yang lain dan memastikan pertanyaan yang dibuat bisa dipahami dan diselesaikan

4. Siswa bersama guru melakukan permainan yang disebut rantai berputar. Yaitu memutar kertas yang berisi pertanyaan sesuai alur yang telah disepakati sesuai dengan tempat duduk. Kegiatan ini diiringi dengan menyanyikan lagu daerah atau lagu nasional. Apabila lagu berhenti maka setiap siswa menuliskan pertanyaan yang ada dalam kertas warna. Kegiatan ini diulang hingga setiap siswa mendapatkan 10 pertanyaan yang berbeda. Apabila semua siswa telah mempunyai sepuluh pertanyaan maka permainan dihentikan dan siswa menjawab pertanyaan yang sudah ditulis. Kertas berwarna yang berisi pertanyaan kemudian dikumpulkan kepada guru

5. Setelah itu siswa bersama-sama melakukan kuis, guru membagi siswa menjadi 5 kelompok masing-masing kelompok terdiri dari 4-5 orang siswa. Pembagian ini dilakukan dengan cara siswa secara bergantian mengucapkan "TAK", "TIK", "BOOM", "DAAR" dan "DOOR". Siswa akan berkelompok sesuai dengan kata yang diucapkannya. Kuis ini diberi nama kuis "Anak Cerdas". Pada kegiatan ini dibagi menjadi beberapa babak. Babak I kuis ini adalah cepat tepat, maksudnya guru membacakan satu pertanyaan dan peserta beradu cepat menuliskan jawaban yang sesuai. Babak II adalah babak tepat waktu, maksudnya guru membacakan satu pertanyaan dan semua peserta atau kelompok diberi waktu 10 detik untuk menuliskan jawaban pada kertas yang sudah disediakan dengan menggunakan spidol. Saat waktu berkahir setiap peserta yang mewakili kelompoknya memperlihatkan jawabannya. Babak III adalah cepat tangkas, maksudnya setiap kelompok memilih satu amplop yang sudah berisi jawaban. Masing-masing kelompok satu persatu secara bergantianmengambil jawaban yang ada kemudian menyusun pertanyaan untuk orang pertama. Jika tidak bisa dapat dilewati. Bagi pesrta yang baru saja mendapat pertanyaan bergantian mengambil jawaban dan membuat pertanyaan untuk orang pertama berikutnya dan untuk siswa yang baru saja membuat pertanyaan kembali ke barisan kelompoknya. Bagi kelompok yang menjawab dengan benar maka guru menuliskan perolehan skor pada papan skor. Kuis ini di setting bagaimana seluruh anggota kelompok terlibat dan memainkan perannya.

Langkah-langkah di atas dilakukan pada setiap siklus yang akan dilalui. Karena banyaknya waktu yang dibutuhkan dalam menerapkan metode tersebut maka setiap siklus dialokasikan 2 kali pertemuan. Sehingga sampai tuntas pelaksanaan penelitian ini dibutuhkan 4 kali tatap muka. 
Minto Santoso. 2018. Penerapan Metode Ceria Permanis untuk Meningkatkan Partisipasi dan Prestasi Belajar Pkn Siswa Kelas VII SMPI Hidayatul ‘Ulum Dayu Semester Genap

Tahun Pelajaran 2017/ 2018. Konstruktivisme, 10 (2): 163-177

\section{HASIL DAN PEMBAHASAN}

\section{A. HASIL}

a. Hasil belajar pada pra tindakan

Tabel 1. Hasil belajar siswa pada pra tindakan

\begin{tabular}{|c|c|c|c|c|}
\hline \multirow{2}{*}{ No } & \multirow{2}{*}{ Nama } & \multirow{2}{*}{ Nilai akhir } & \multicolumn{2}{|c|}{ Ketuntasan } \\
\hline & & & $\mathrm{T}$ & $B T$ \\
\hline 1 & A. Alwi Fuadzin & 70 & & $B T$ \\
\hline 2 & Angga Abnaul Muiz & 86 & $\mathrm{~T}$ & \\
\hline 3 & A. Muafikurrahman & 65 & & $B T$ \\
\hline 4 & Carrol Dewa Satria & 72 & & $B T$ \\
\hline 5 & Dewi Nurhamida & 81 & $\mathrm{~T}$ & \\
\hline 6 & Devi Rahayu & 80 & $\mathrm{~T}$ & \\
\hline 7 & Dian Zunis T & 81 & $\mathrm{~T}$ & \\
\hline 8 & Dwi Ridhoul & 82 & $\mathrm{~T}$ & \\
\hline 9 & Edo Pratama & 60 & & $B T$ \\
\hline 10 & Liza Hidayatus S & 84 & $\mathrm{~T}$ & \\
\hline 11 & M. Latiful Jamil & 74 & & $B T$ \\
\hline 12 & M. Aris & 82 & $\mathrm{~T}$ & \\
\hline 13 & M. Anwarul Huda & 80 & $\mathrm{~T}$ & \\
\hline 14 & Nuriska Lutfina & 80 & $\mathrm{~T}$ & \\
\hline 15 & Resa Nur Azizah & 92 & $\mathrm{~T}$ & \\
\hline 16 & Riska Binti K & 69 & & $B T$ \\
\hline 17 & Rizqina Mahmudatun & 74 & $\mathrm{~T}$ & \\
\hline 18 & Sigit Eko Cahyono & 72 & & $B T$ \\
\hline 19 & Zidan Hamid & 62 & & $B T$ \\
\hline 20 & Zahro Nur Fitri & 81 & $\mathrm{~T}$ & \\
\hline 21 & Feri Ardian & 65 & & $B T$ \\
\hline 22 & Oktasariatus S & 88 & $\mathrm{~T}$ & $B T$ \\
\hline \multicolumn{2}{|c|}{ Jumlah } & 1660 & 12 & 10 \\
\hline \multicolumn{2}{|c|}{ Rata-rata } & 75,5 & & \\
\hline \multicolumn{2}{|c|}{$\%$ Ketuntasan } & & $54,6 \%$ & $45,4 \%$ \\
\hline \multicolumn{2}{|c|}{ Kriteria Tingkat Keberhasilan } & Cukup & & \\
\hline
\end{tabular}


Minto Santoso. 2018. Penerapan Metode Ceria Permanis untuk Meningkatkan Partisipasi dan Prestasi Belajar Pkn Siswa Kelas VII SMPI Hidayatul 'Ulum Dayu Semester Genap

Tahun Pelajaran 2017/ 2018. Konstruktivisme, 10 (2): 163-177

\section{b. Hasil pengamatan partisipasi siswa pada pra siklus}

Tabel 2 : Hasil pengamatan partisipasi siswa pada pra tindakan

No

Aspek yang Diamati

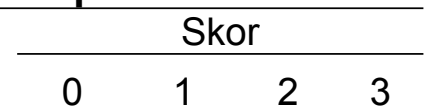

1. Mendengarkan presensi, menanggapi presensi dan memperhatikan motivasi guru

2. Menjawab permasalahan yang disajikan guru dan menanggapi berdasarkan pengetahuan yang dimilikinya.

3. Melakukan kegiatan yaitu memperhatikan penjelasan dari guru, menyampaikan pendapat dan bertanya mengenai materi yang telah disampaikan oleh guru.

4. Mendengarkan pengarahan dari guru dan melakukan permainan.

5. Mendengarkan pengarahan dari guru memperhatikan demonstrasi guru dan melaksanakan kuis dengan baik.

6. Mengungkapkan tentang apa yang dipelajari dan mendiskripsikan pengetahuan yang diperolehnya.

$$
\begin{aligned}
\text { Persentase nilai rata-rata } & =\frac{\text { Jumlah skor }}{18} \times 100 \% \\
& =\frac{2+1+1+0+0+0}{18} \times 100 \% \\
& =22.2 \%
\end{aligned}
$$

\begin{tabular}{|c|c|c|c|c|c|c|}
\hline \multirow[t]{2}{*}{ No } & \multirow[t]{2}{*}{ Nama } & \multicolumn{3}{|c|}{ Penilian } & \multirow[b]{2}{*}{$\mathrm{Jml}$} & \multirow[b]{2}{*}{$\begin{array}{l}\text { Nilai } \\
\text { akhir }\end{array}$} \\
\hline & & $\begin{array}{c}\text { Nilai Game } \\
\text { (N1) }\end{array}$ & $\begin{array}{c}\text { Nilai Proses } \\
\text { (N2) }\end{array}$ & $\begin{array}{l}\text { Butir tes } \\
\text { (N3) }\end{array}$ & & \\
\hline 1 & A. Alwi Fuadzin & 65 & 75 & 65 & 205 & 68 \\
\hline 2 & Angga Abnaul Muiz & 90 & 100 & 100 & 290 & 97 \\
\hline 3 & A. Muafikurrahman & 70 & 100 & 75 & 245 & 82 \\
\hline 4 & Carrol Dewa Satria & 70 & 83 & 80 & 233 & 78 \\
\hline 5 & Dewi Nurhamida & 75 & 100 & 80 & 255 & 85 \\
\hline 6 & Devi Rahayu & 70 & 100 & 75 & 245 & 82 \\
\hline 7 & Dian Zunis T & 80 & 100 & 90 & 270 & 90 \\
\hline 8 & Dwi Ridhoul & 80 & 100 & 90 & 270 & 90 \\
\hline 9 & Edo Pratama & 70 & 92 & 90 & 257 & 87 \\
\hline 10 & Liza Hidayatus S & 85 & 100 & 95 & 280 & 93 \\
\hline 11 & M. Latiful Jamil & 75 & 92 & 70 & 237 & 79 \\
\hline 12 & M. Aris & 85 & 90 & 80 & 255 & 85 \\
\hline 13 & M. Anwarul Huda & 60 & 92 & 60 & 212 & 70 \\
\hline 14 & Nuriska Lutfina & 65 & 83 & 70 & 218 & 73 \\
\hline 15 & Resa Nur Azizah & 90 & 100 & 95 & 285 & 95 \\
\hline
\end{tabular}

\section{c. Hasil akhir siklus I}

Tabel.3: Hasil belajar siklus I 
Minto Santoso. 2018. Penerapan Metode Ceria Permanis untuk Meningkatkan Partisipasi dan Prestasi Belajar Pkn Siswa Kelas VII SMPI Hidayatul ‘Ulum Dayu Semester Genap

Tahun Pelajaran 2017/ 2018. Konstruktivisme, 10 (2): 163-177

16 Riska Binti K

80

100

85

265

88 
Minto Santoso. 2018. Penerapan Metode Ceria Permanis untuk Meningkatkan Partisipasi dan Prestasi Belajar Pkn Siswa Kelas VII SMPI Hidayatul 'Ulum Dayu Semester Genap

Tahun Pelajaran 2017/ 2018. Konstruktivisme, 10 (2): 163-177

\begin{tabular}{|c|c|c|c|c|c|c|}
\hline \multirow[t]{2}{*}{ No } & \multirow[t]{2}{*}{ Nama } & \multicolumn{3}{|c|}{ Penilian } & \multirow[b]{2}{*}{$\mathrm{Jml}$} & \multirow[b]{2}{*}{$\begin{array}{l}\text { Nilai } \\
\text { akhir }\end{array}$} \\
\hline & & $\begin{array}{c}\text { Nilai Game } \\
\text { (N1) }\end{array}$ & $\begin{array}{c}\text { Nilai Proses } \\
\text { (N2) }\end{array}$ & $\begin{array}{c}\text { Butir tes } \\
\text { (N3) }\end{array}$ & & \\
\hline 17 & Rizqina Mahmudatun & 85 & 100 & 90 & 275 & 92 \\
\hline 18 & Sigit Eko Cahyono & 60 & 83 & 60 & 203 & 67 \\
\hline 19 & Zidan Hamid & 70 & 100 & 75 & 245 & 82 \\
\hline 20 & Zahro Nur Fitri & 70 & 100 & 80 & 250 & 84 \\
\hline 21 & Feri Ardian & 75 & 100 & 75 & 250 & 84 \\
\hline 22 & Oktasariatus S & 90 & 100 & 95 & 285 & 95 \\
\hline \multicolumn{2}{|c|}{ Jumlah } & 1660 & 2090 & 1775 & 5530 & 1846 \\
\hline \multicolumn{2}{|c|}{ Rata-rata } & 75,5 & 95,0 & 80,7 & 251,4 & 83,9 \\
\hline
\end{tabular}

Nilai Akhir (NA)

$$
\begin{aligned}
& =\frac{N 1+N 2+N 3 \times 100 \%}{3} \times 1 \\
& =\frac{1660+2090+1775}{3} \times 100 \% \\
& =80,7 \%
\end{aligned}
$$

Kriteria taraf keberhasilan tindakan ditentukan sebagai berikut:
$85 \%<\mathrm{NR} \leq 100 \%$
: Sangat baik
$70 \%<\mathrm{NR} \leq 84 \%$
: Baik
$55 \%<\mathrm{NR} \leq 69 \%$
: Cukup baik
$45 \%<\mathrm{NR} \leq 54 \%$
: Kurang baik
$0 \%<N R \leq 44 \%$
: Sangat kurang baik

\section{d. Hasil pengamatanpartisipasi siswa siklus I}

Tabel.4 : Hasil pengamatan partisipasi siswa pada siklus I

\begin{tabular}{|l|l|l|l|l|l|}
\hline \multirow{2}{*}{ No } & \multicolumn{1}{|c|}{ Aspek yang Diamati } & \multicolumn{3}{|c|}{ Skor } \\
\cline { 3 - 5 } & \multicolumn{1}{|c|}{} & & 1 & 2 & 3 \\
\hline 1. & $\begin{array}{l}\text { Mendengarkan presensi, menanggapi presensi dan } \\
\text { memperhatikan motivasi guru }\end{array}$ & & $\sqrt{ }$ & \\
\hline 2. & $\begin{array}{l}\text { Menjawab permasalahan yang disajikan guru dan } \\
\text { menanggapi berdasarkan pengetahuan yang } \\
\text { dimilikinya. }\end{array}$ & & $\sqrt{ }$ & \\
\hline 3. & $\begin{array}{l}\text { Melakukan kegiatan yaitu memperhatikan penjelasan } \\
\text { dari guru, menyampaikan pendapat dan bertanya } \\
\text { mengenai materi yang telah disampaikan oleh guru. }\end{array}$ & & & & $\sqrt{ }$ \\
\hline 4. & $\begin{array}{l}\text { Mendengarkan pengarahan dari guru dan melakukan } \\
\text { permainan. }\end{array}$ & & & $\sqrt{ }$ \\
\hline 5. & $\begin{array}{l}\text { Mendengarkan pengarahan dari guru memperhatikan } \\
\text { demonstrasi guru dan melaksanakan kuis dengan baik. }\end{array}$ & & & $\sqrt{ }$ & \\
\hline 6. & $\begin{array}{l}\text { Mengungkapkan tentang apa yang dipelajari dan } \\
\text { mendiskripsikan pengetahuan yang diperolehnya. }\end{array}$ & & & & \\
\hline
\end{tabular}


Minto Santoso. 2018. Penerapan Metode Ceria Permanis untuk Meningkatkan Partisipasi dan Prestasi Belajar Pkn Siswa Kelas VII SMPI Hidayatul 'Ulum Dayu Semester Genap

Tahun Pelajaran 2017/ 2018. Konstruktivisme, 10 (2): 163-177

Keterangan Tabel 4 Hasil pengamatan partisipasi siswa pada siklus I

Persentase nilai rata-rata $=\frac{\text { Jumlah skor }}{18} \times 100 \%$

$$
=\frac{2+2+2+3+3+2}{18} \times 100 \%=77.8 \%
$$

Kriteria taraf keberhasilan tindakan ditentukan sebagai berikut:

$$
\begin{array}{ll}
85 \%<N R \leq 100 \% & : \text { Sangat baik } \\
70 \%<N R \leq 84 \% & : \text { Baik } \\
55 \%<N R \leq 69 \% & : \text { Cukup baik } \\
45 \%<N R \leq 54 \% & : \text { Kurang baik } \\
0 \%<N R \leq 44 \% & : \text { Sangat kurang baik }
\end{array}
$$

\begin{tabular}{|c|c|c|c|c|c|c|}
\hline \multirow[t]{2}{*}{ No } & \multirow[t]{2}{*}{ Nama } & \multicolumn{3}{|c|}{ Penilaian } & \multirow[t]{2}{*}{$\mathrm{Jml}$} & \multirow{2}{*}{$\begin{array}{l}\text { Nilai } \\
\text { akhir }\end{array}$} \\
\hline & & $\begin{array}{c}\text { Nilai Game } \\
\text { (N1) }\end{array}$ & $\begin{array}{c}\text { Nilai Proses } \\
\text { (N2) }\end{array}$ & $\begin{array}{l}\text { Butir tes } \\
\text { (N3) }\end{array}$ & & \\
\hline 1 & A. Alwi Fuadzin & 80 & 100 & 0 & 180 & 60 \\
\hline 2 & Angga Abnaul Muiz & 95 & 100 & 100 & 295 & 98 \\
\hline 3 & A. Muafikurrahman & 75 & 100 & 80 & 255 & 85 \\
\hline 4 & Carrol Dewa Satria & 80 & 100 & 80 & 260 & 87 \\
\hline 5 & Dewi Nurhamida & 85 & 100 & 80 & 265 & 88 \\
\hline 6 & Devi Rahayu & 80 & 100 & 75 & 255 & 85 \\
\hline 7 & Dian Zunis T & 80 & 100 & 90 & 270 & 90 \\
\hline 8 & Dwi Ridhoul & 80 & 100 & 90 & 270 & 90 \\
\hline 9 & Edo Pratama & 75 & 100 & 85 & 260 & 87 \\
\hline 10 & Liza Hidayatus S & 90 & 100 & 95 & 285 & 95 \\
\hline 11 & M. Latiful Jamil & 80 & 100 & 80 & 260 & 87 \\
\hline 12 & M. Aris & 0 & 0 & 90 & 90 & 93 \\
\hline 13 & M. Anwarul Huda & 80 & 100 & 80 & 260 & 87 \\
\hline 14 & Nuriska Lutfina & 75 & 92 & 80 & 247 & 82 \\
\hline 15 & Resa Nur Azizah & 95 & 100 & 95 & 290 & 97 \\
\hline 16 & Riska Binti K & 85 & 100 & 85 & 270 & 90 \\
\hline 17 & Rizqina Mahmudatun & 85 & 100 & 90 & 275 & 92 \\
\hline 18 & Sigit Eko Cahyono & 80 & 92 & 75 & 247 & 82 \\
\hline 19 & Zidan Hamid & 80 & 100 & 80 & 260 & 87 \\
\hline 20 & Zahro Nur Fitri & 85 & 100 & 85 & 270 & 90 \\
\hline 21 & Feri Ardian & 80 & 92 & 75 & 247 & 82 \\
\hline 22 & Oktasariatus S & 95 & 100 & 95 & 290 & 97 \\
\hline \multicolumn{2}{|c|}{ Jumlah } & 1740 & 2076 & 1785 & 5601 & 1868 \\
\hline \multicolumn{2}{|c|}{ Rata-rata } & 79,1 & 94,4 & 81,1 & 254,6 & 84,9 \\
\hline
\end{tabular}

\section{e. Hasil Akhir siklus II}

Tabel.5 : Hasil prestasi belajar siklus II 
Minto Santoso. 2018. Penerapan Metode Ceria Permanis untuk Meningkatkan Partisipasi dan Prestasi Belajar Pkn Siswa Kelas VII SMPI Hidayatul 'Ulum Dayu Semester Genap Tahun Pelajaran 2017/ 2018. Konstruktivisme, 10 (2): 163-177

Keterangan Tabel.5 : Hasil prestasi belajar siklus II

Nilai Akhir (NA)

$$
\begin{aligned}
& =\frac{N 1+N 2+N 3 \times 100 \%}{3} \times \\
& =\frac{1740+2076+1785}{3} \times 100 \% \\
& =84,9 \%
\end{aligned}
$$

Kriteria taraf keberhasilan tindakan ditentukan sebagai berikut:
$85 \%<\mathrm{NR} \leq 100 \% \quad$ : Sangat baik
$70 \%<\mathrm{NR} \leq 84 \% \quad$ : Baik
$55 \%<\mathrm{NR} \leq 69 \% \quad$ : Cukup baik
$45 \%<\mathrm{NR} \leq 54 \% \quad$ : Kurang baik
$0 \%<N R \leq 44 \% \quad$ : Sangat kurang baik

\begin{tabular}{|c|c|c|c|c|c|}
\hline \multirow[b]{2}{*}{ No } & \multirow[b]{2}{*}{ Aspek yang Diamati } & \multicolumn{4}{|c|}{ Skor } \\
\hline & & 0 & 1 & 2 & 3 \\
\hline 1. & $\begin{array}{l}\text { Mendengarkan presensi, menanggapi presensi dan } \\
\text { memperhatikan motivasi guru }\end{array}$ & & & & $\sqrt{ }$ \\
\hline 2. & $\begin{array}{l}\text { Menjawab permasalahan yang disajikan guru dan } \\
\text { menanggapi berdasarkan pengetahuan yang dimilikinya. }\end{array}$ & & & $\sqrt{ }$ & \\
\hline 3. & $\begin{array}{l}\text { Melakukan kegiatan yaitu memperhatikan penjelasan } \\
\text { dari guru, menyampaikan pendapat dan bertanya } \\
\text { mengenai materi yang telah disampaikan oleh guru. }\end{array}$ & & & & $\sqrt{ }$ \\
\hline 4. & $\begin{array}{l}\text { Mendengarkan pengarahan dari guru dan melakukan } \\
\text { permainan. }\end{array}$ & & & & $\sqrt{ }$ \\
\hline 5. & $\begin{array}{l}\text { Mendengarkan pengarahan dari guru memperhatikan } \\
\text { demonstrasi guru dan melaksanakan kuis dengan baik. }\end{array}$ & & & & $\sqrt{ }$ \\
\hline 6. & $\begin{array}{l}\text { Mengungkapkan tentang apa yang dipelajari dan } \\
\text { mendiskripsikan pengetahuan yang diperolehnya. }\end{array}$ & & & & $\sqrt{ }$ \\
\hline
\end{tabular}

\section{f. Hasil Pengamatan Partisipasi siswa siklus II}

Tabel.6 : Hasil pengamtan partisipasi siswa siklus II

$$
\begin{aligned}
\text { Persentase nilai rata-rata (PNR) } & =\frac{\text { Jumlah skor }}{18} \times 100 \% \\
& =\frac{3+2+3+3+3+3}{18} \times 100 \% \\
& =94,44 \%
\end{aligned}
$$

Kriteria taraf keberhasilan tindakan ditentukan sebagai berikut:

$$
\begin{array}{ll}
85 \%<N R \leq 100 \% & : \text { Sangat baik } \\
70 \%<N R \leq 84 \% & : \text { Baik } \\
55 \%<N R \leq 69 \% & : \text { Cukup baik } \\
45 \%<N R \leq 54 \% & : \text { Kurang baik } \\
0 \%<N R \leq 44 \% & \text { : Sangat kurang baik }
\end{array}
$$


Minto Santoso. 2018. Penerapan Metode Ceria Permanis untuk Meningkatkan Partisipasi dan Prestasi Belajar Pkn Siswa Kelas VII SMPI Hidayatul 'Ulum Dayu Semester Genap

Tahun Pelajaran 2017/ 2018. Konstruktivisme, 10 (2): 163-177 
Minto Santoso. 2018. Penerapan Metode Ceria Permanis untuk Meningkatkan Partisipasi dan Prestasi Belajar Pkn Siswa Kelas VII SMPI Hidayatul ‘Ulum Dayu Semester Genap Tahun Pelajaran 2017/ 2018. Konstruktivisme, 10 (2): 163-177

\section{BAHASAN}

Penggunaan metode ceria permanis terbukti efektif. Hal ini dapat dibuktikan dengan hasil yang diperoleh selalu menunjukkan angka peningkatan. Pada pra siklus angka partisipasi siswa hanya sebesar $22,2 \%$, ini terjadi karena metode pembelajaran sebelumnya hanya menggunakan ceramah biasa saja dan lembar kerja siswa sebagai alat evaluasi. Kegiatan semacam ini terkesan sangat monoton karena mayoritas guru menggunakan cara yang demikian. Setelah dilakukan tindakan berupa penerapan metode ceria permanis partisipasi siswa mengalami kenaikan yang cukup signifikan yaitu sebesar $55,6 \%$ karena perolehan angka partisipasinya $77,8 \%$. Karena target minimal angka partsipasi pada penggunaan metode ini $80 \%$ maka masih perlu dilakukan tindakan pada siklus II. Pada siklus II ini siswa sudah sangat memahami bagaimana menerapkan metode ini bersama-sama dengan guru sehingga perolehan angka partisipasi siswa dalam pembelajaran cukup tinggi yakni $94,4 \%$. Kondisi ini mengalami kenaikan sebesar 16,6\%. Perbandingan angka partisipasi serta peningkatannya dapat dilihat pada diagram ini.

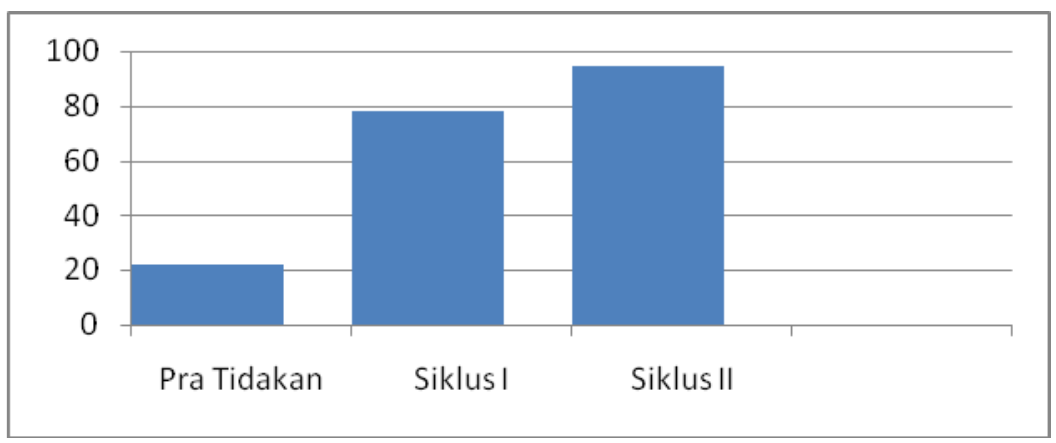

\section{Gambar 1. Perbandingan dan Peningkatan Partisipasi Siswa}

Peningkatan hasil belajar siswa diketahui dengan membandingkan hasil belajar siswa (nilai akhir) pada pra tindakan, siklus I dan siklus II. Hasil belajar pada dasarnya adalah hasil yang dicapai dalam usaha penguasaan materi. Rekapitulasihasil belajar siswa pada pra tindakan, siklus I dan siklus II untuk menjelaskan peningkatan hasil belajar PKn dengan menggunakan metode Ceria Permanissiswa kelas VII SMPI Hidayatul 'Ulum. Tabel.3 menginformasikan bahwa ada peningkatan terhadap hasil belajar siswa. Pada pra tindakan hanya 12 siswa yang tuntas belajar dan 10 siswa lainnya belum tuntas belajar. Ketuntasan ini didasarkan pada perolehan nilai dengan KKM $\geq$ 80. Persentase ketuntasan belajar pada pra tindakan ke siklus I mengalami peningkatan sebesar $25,4 \%$ atau dari $56,4 \%$ (12 siswa tuntas belajar) menjadi $81,8 \%$ (18 siswa tuntas belajar). Sehingga, kriteria tingkat keberhasilan yang semula pada pra tindakan kurang baik meningkat pada siklus I dengan kriteria 
Minto Santoso. 2018. Penerapan Metode Ceria Permanis untuk Meningkatkan Partisipasi dan Prestasi Belajar Pkn Siswa Kelas VII SMPI Hidayatul ‘Ulum Dayu Semester Genap

Tahun Pelajaran 2017/ 2018. Konstruktivisme, 10 (2): 163-177

sangat baik. Karena target ketuntasan pada kelas ini lebih dari $85 \%$ maka perlu dilakukan tindakan pada siklus II. Presentase ketuntasan belajar pada siklus I ke siklus II mengalami peningkatan 9,1\% atau dari 81,8\% (18 siswa tuntas belajar) menjadi sebesar $90,9 \%$ (20 siswa tuntas belajar). Pada siklus II ini ada 2 siswa yang tidak mengikuti pembelajaran secara penuh. Satu siswa tidak ikut dipertemuan pertama dan satu siswa tidak ikut dipertemuan kedua. Peningkatan hasil belajar juga ditunjukkan dengan meningkatnya nila rata-rata kelas yang pada saat pra siklus 75,5 menjadi 83,9 pada siklus I dan 84,9 pada pada siklus II. Peningkatan ini merupakan manfaat diterapkannya metode Ceria Permanis di kelas VII SMPI Hidayatul 'Ulum tahun pelajaran 2017/ 2018 pada semester genap.

Secara keseluruhan perbandingan dan peningkatan hasil belajar dan partisipasi belajar PKn siswa kelas VII SMPI Hidayatul 'Ulum Dayu tahun pelajaran 2017/ 2018 semester genap sebagai berikut:

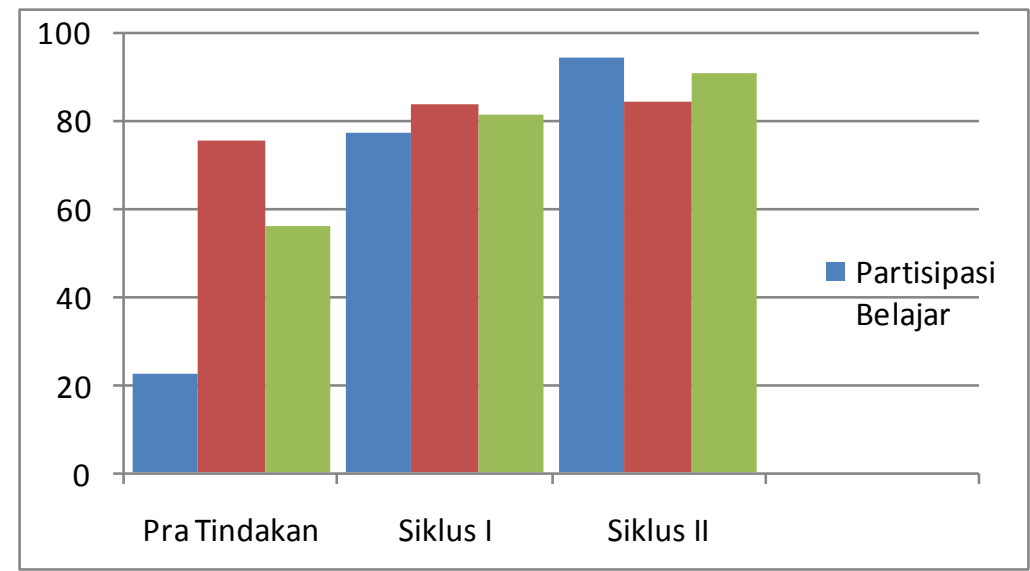

Gambar 2. Perbandingan dan peningkatan hasil belajar dan partisipasi belajar PKn

Pembelajaran dengan menerapkan metode Ceria Permanis merupakan pembelajaran yang tepat diterapkan di Kelas VII SMPI Hidayatul 'Ulum Dayu Kecamatan Nglegok Kabupaten Blitar karena metodeCeria Permanis menjadikan suasana belajar siswa lebih bermakna karena siswa belajar dari masalah dalam kehidupan sehari-hari, selanjutnya siswa menyelesaikan masalah yang disajikan guru dengan tindakan menemukan, menganalisis. Dalam kegiatan belajar siswa bertanya baik antar siswa maupun guru dengan siswa. Selanjutnya siswa turut aktif dalam setiap pembelajaran baik itu permainan maupun kuis.

\section{SIMPULAN}

1. Penerapan metode ceria permanis yaitu dengan langkah: 1)ceramah yang disertai dengan tanya jawab, variasi intonasi, variasi tinggi rendah 
Minto Santoso. 2018. Penerapan Metode Ceria Permanis untuk Meningkatkan Partisipasi dan Prestasi Belajar Pkn Siswa Kelas VII SMPI Hidayatul ‘Ulum Dayu Semester Genap

Tahun Pelajaran 2017/ 2018. Konstruktivisme, 10 (2): 163-177

suara serta disertai dengan variasi perubahan gesture dan gerak tubuh, 2) melakukan permainan yang disebut rantai berputar. Yaitu memutar kertas yang berisi pertanyaan sesuai alur yang telah disepakati sesuai dengan tempat duduk. Kegiatan ini diiringi dengan menyanyikan lagu daerah atau lagu nasional. Apabila lagu berhenti maka setiap siswa menuliskan pertanyaan yang ada dalam kertas warna. Kegiatan ini diulang hingga setiap siswa mendapatkan 10 pertanyaan yang berbeda. Apabila semua siswa telah mempunyai sepuluh pertanyaan maka permainan dihentikan dan siswa menjawab pertanyaan yang sudah ditulis. Kertas berwarna yang berisi pertanyaan kemudian dikumpulkan kepada guru, 3) melakukankuis"Anak Cerdas" secara berkelompok yang beranggotakan 4 sampai 5 siswa. Babak I kuis ini adalah cepat tepat, guru membacakan satu pertanyaan dan peserta beradu cepat menuliskan jawaban yang sesuai. Babak II adalah babak tepat waktu, guru membacakan satu pertanyaan dan semua peserta atau kelompok diberi waktu 10 detik untuk menuliskan jawaban pada kertas yang sudah disediakan dengan menggunakan spidol. Saat waktu berakhir setiap peserta yang mewakili kelompoknya memperlihatkan jawabannya. Babak III adalah cepat tangkas, setiap kelompok memilih satu amplop yang sudah berisi jawaban. Masing-masing kelompok satu persatu secara bergantianmengambil jawaban yang ada kemudian menyusun pertanyaan untuk orang pertama. Jika tidak bisa dapat dilewati. Bagi peserta yang baru saja mendapat pertanyaan bergantian mengambil jawaban dan membuat pertanyaan untuk orang berikutnya dan untuk siswa yang baru saja membuat pertanyaan kembali ke barisan kelompoknya.

2. Penerapan metode ceria permanis dapat meningkatkan partsipasi dan hasil belajar siswa kelas VII SMPI Hidayatul 'Ulum. Partisipasi siswa pada pra siklus yang hanya sebesar $22,2 \%$, setelah menggunakan metode ini capaian akhir partisipasi siswa 94,4\%. Peningkatan partisipasi siswa juga diikuti peningkatan hasil belajar yakni dari $56, \%$ saat pra siklus menjadi $90,9 \%$ pada akhir siklus.

\section{DAFTAR RUJUKAN}

A.M Sudirman. 2011. Interaksi dan Motivasi Belajar dan Mengajar.Jakarta : PT. Grafindo Indonesia.

Ahmadi, A., \& Widodo, S. 2013. Psikologi Belajar. Jakarta: Rineka Cipta.

Arikunto, Suharsimi. 2015. Penelitian Tindakan Kelas edisi. Jakarta: Bumi Aksara 
Minto Santoso. 2018. Penerapan Metode Ceria Permanis untuk Meningkatkan Partisipasi dan Prestasi Belajar Pkn Siswa Kelas VII SMPI Hidayatul ‘Ulum Dayu Semester Genap Tahun Pelajaran 2017/ 2018. Konstruktivisme, 10 (2): 163-177

Asri, Ade. 2013. Penerapan Metode Ceramah Bervariasi untuk Meningkatkan Motivasi Belajar Siswa dalam Pembelajaran PKn. (http://repository.upi.edu/424/3/S_PKN_0901624_CHAPTER1.pdf).

Djamarah. S. B, Zain. A. 2010. Strategi Belajar Mengajar. Jakarta: Rineka Cipta

Miftahul Huda. 2013. Model - Model Pengajaran dan Pembelajaran. Yogyakarta: Pustaka Pelajar

M. Thobroni.2015. Belajar \& Pembelajaran - Teori dan Praktik. Yogyakarta: Ar. Ruzz Media

Santoso, Minto. 2017. Penerapan Metode Teka-Teki Petualang untuk Meningkatkan Hasil Belajar Mahasiswa Program Studi PGSD Semester VI Universitas Islam Balitar Blitar Pada Mata Kuliah Pembelajaran Pkn SD Tahun Akademik 2016/ 2017. Konstruktivisme, 9 (2). 